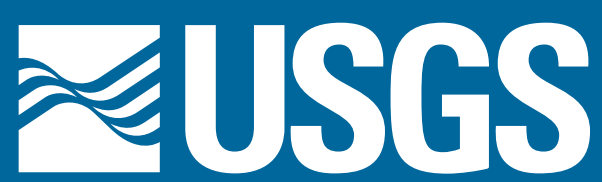

\title{
Floods of May 2006 and April 2007 in Southern Maine
}

\author{
The U.S. Geological Survey Maine Water Science Center has worked with the Federal Emergency \\ Management Agency for decades to document the magnitude and extent of major floods in Maine. Reports \\ describing the May 2006 and April 2007 floods in southern Maine are examples of this cooperative relationship. \\ The documentation of peak stream elevations and peak streamflow magnitudes and recurrence intervals \\ provides essential information for the delineation of flood plains and for flood-mitigation decisions by local, \\ State, and Federal emergency management officials.
}

\section{Introduction}

Extreme floods occurred on streams in southern Maine in May 2006 and in April 2007 (fig.1). Floods with recurrence intervals greater than 100 years (having less than a 1-percent probability of exceedence each year) occurred during the Mother's Day Storm of May 2006 and the Patriots' Day Storm of April 2007. Although both storms were centered in York County, the 2006 storm resulted in higher streamflows near the coast, and the 2007 storm resulted in flooding over a wider geographical area-extending into Cumberland County and western York County.

The documentation of peak stream elevations and peak streamflow magnitudes and recurrence intervals associated

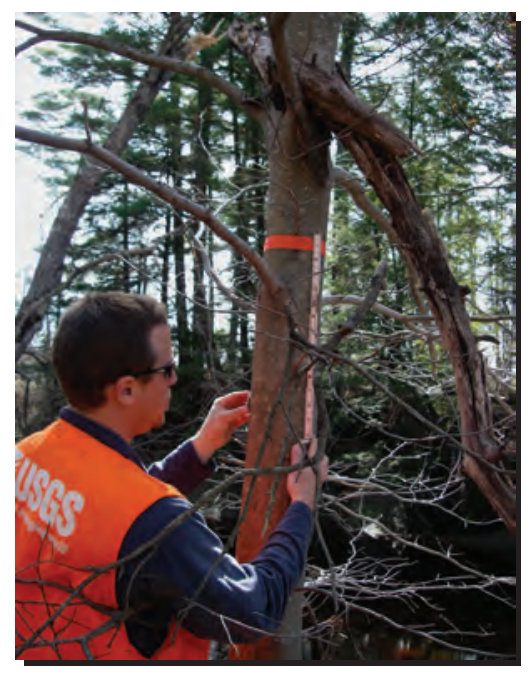

Figure 2. Identifying high water marks in southern Maine 2007.

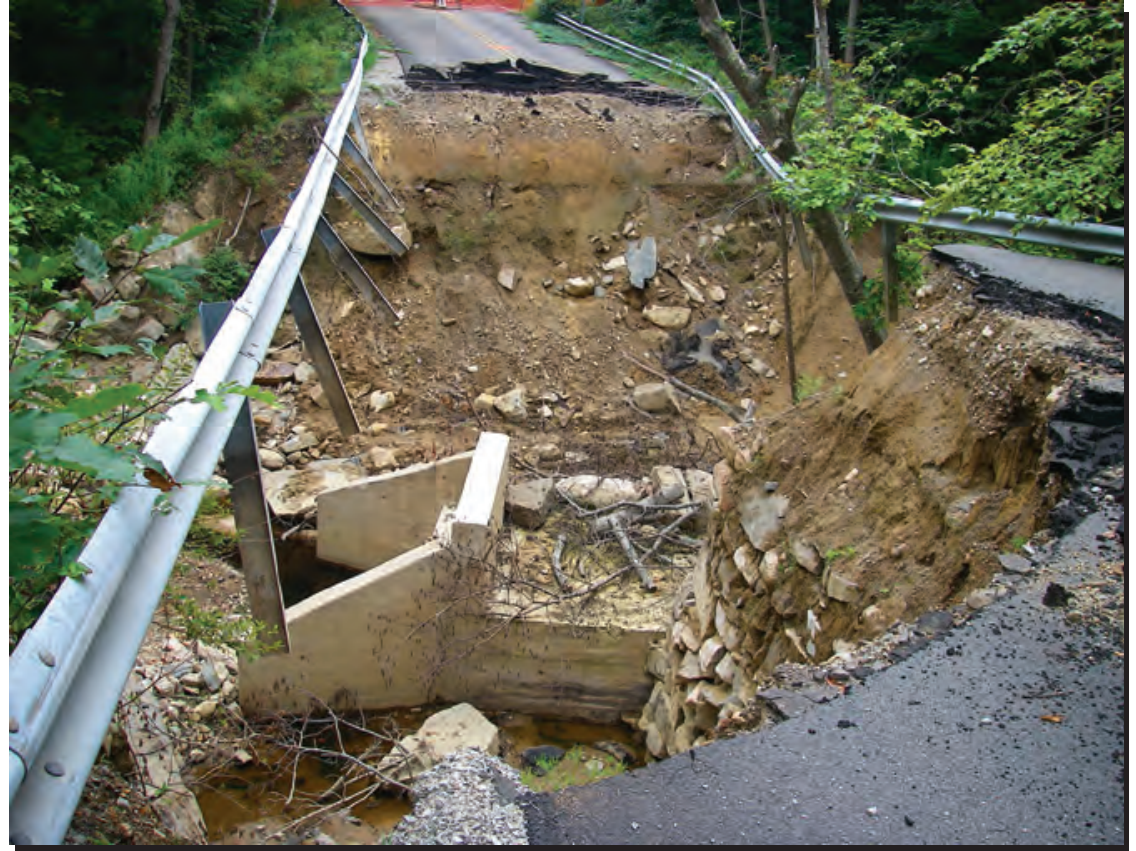

Figure 1. Josias River washout of culvert, York County, Maine, May 2006.

with extreme floods is important for the calibration of models used to delineate 100- and 500-year flood plains in regulatory flood-insurance studies. Minimal historical peak-flow data are available for southern Maine; however, riverine floods occurred in 1936, 1953, 1987, and 1996.

\section{Storm Characteristics}

The Mother's Day Storm from May 10-17, 2006, was characterized by up to 16 inches (in.) of rain falling on saturated ground in locations centered around Ogunquit, Maine. The wettest month of May since 1871 (12.3 in.) was recorded in
Portland, Maine, in 2006. Cape

Neddick received 20.3 in. of rain in May 2006 (National Weather Service, 2008). Rainfall received during the Mother's Day Storm exceeded the 100-year recurrence interval for 2-, 4-, 7-, and 10-day rainfall totals at many locations in southern Maine.

The Patriots' Day Storm from April 15-18, 2007, dropped up to 8.5 in. of rain over much of southern Maine-from the western border with New Hampshire to the coast (National Weather Service, 2008) - and was augmented with up to 1 in. of water from snowmelt. The average rainfall for the Patriots' Day Storm 
was roughly equivalent to the 100 -year recurrence interval for 2-day rainfall totals at selected locations in southern Maine.

\section{Peak Stream Elevations}

Peak stream elevations were determined for 80 points at 25 sites in York County following the May 2006 flood and 160 points at 63 sites in York and Cumberland Counties following the April 2007 flood. Most peak stream elevations were determined through the identification and surveying of high-water marks immediately following the floods.

\section{Peak Streamflow Magnitudes and Recurrence Intervals}

Peak streamflow magnitudes and recurrence intervals (such as the 100-year peak streamflow) were calculated for the May 2006 flood at 9 locations and for the April 2007 flood at 24 locations in southern Maine (fig. 3). Peak streamflows were higher in 2006 at five of the nine locations for which peak streamflows were calculated for both years (table 1).

The most reliable method for computing peak streamflows is from a rating (relation between streamflow and stream elevation at a streamflow-gaging station). If a rating is unavailable or unreliable for extremely high flows, peak streamflow can be calculated using a hydraulic model based on relations between streamflow and the geometry of the stream channel. Peak

Table 1. May 2006 and April 2007 peak streamflows for selected sites in southern Maine.

$\left[\mathrm{ft}^{3} / \mathrm{s}\right.$, cubic feet per second]

\begin{tabular}{|c|c|c|}
\hline Stream and location & $\begin{array}{c}2006 \\
\text { Peak } \\
\text { flow } \\
\left(\mathrm{ft}^{3} / \mathrm{s}\right)\end{array}$ & $\begin{array}{c}2007 \\
\text { Peak } \\
\text { flow } \\
\left(\mathrm{ft}^{3} / \mathrm{s}\right)\end{array}$ \\
\hline $\begin{array}{r}\text { Mousam River near } \\
\text { West Kennebunk }\end{array}$ & 6,100 & 9,230 \\
\hline Little River, Berwick & 3,390 & 4,640 \\
\hline Cape Neddick River, York & 2,250 & 1,010 \\
\hline Ogunquit River, Ogunquit & 3,110 & 2,230 \\
\hline Blacksmith Brook, Wells & 473 & 260 \\
\hline Merriland River, Wells & 2,240 & 1,860 \\
\hline $\begin{array}{l}\text { Branch Brook near } \\
\text { Kennebunk }\end{array}$ & 1,500 & 1,330 \\
\hline $\begin{array}{c}\text { Stony Brook at } \\
\text { East Sebago }\end{array}$ & 40 & 125 \\
\hline Saco River at Cornish & 14,900 & 17,000 \\
\hline
\end{tabular}

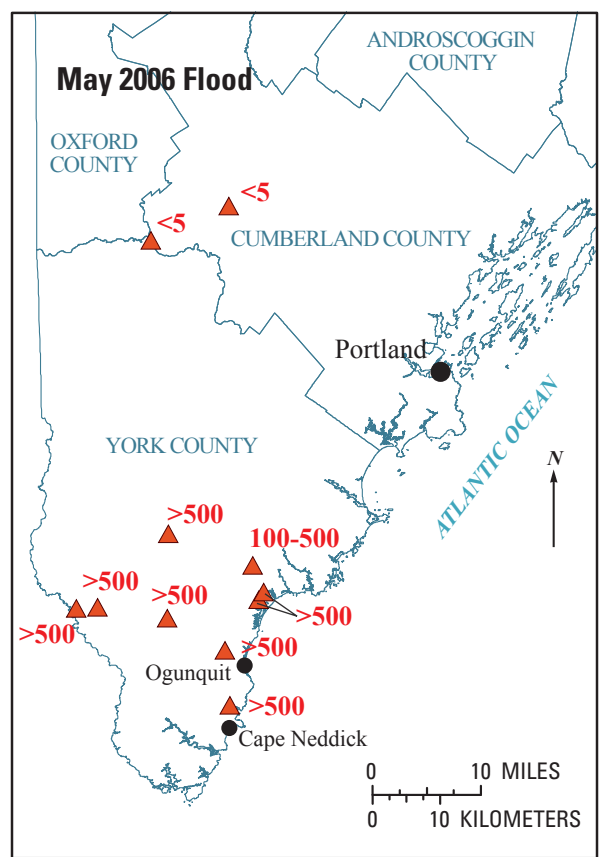

Base from U.S. Geological Survey and

Maine Office of Geographic Information System digital files,

North American Datum 83, Universal Transverse Mercator grid, Zone 19

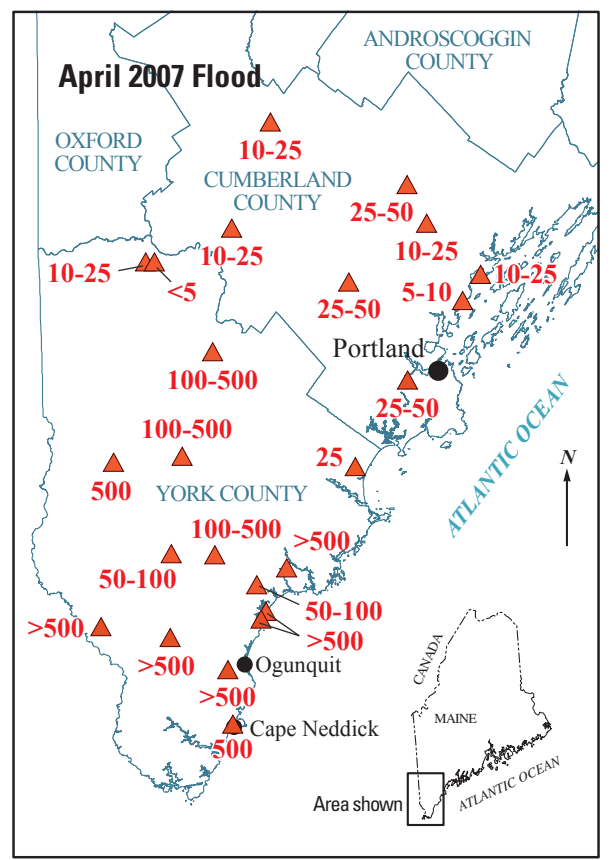

EXPLANATION

$\triangle 500$ Streamflow site and recurrence interval $>\quad$ greater than

$<$ less than

Figure 3. Peak-streamflow recurrence intervals associated with the May 2006 flood and April 2007 flood at selected sites in southern Maine.

streamflow recurrence intervals were greater than 100 years for much of York County during both the May 2006 and April 2007 floods - and were up to 50 years in Cumberland County during the April 2007 flood (fig. 3).

It is possible to have storms with large recurrence intervals in consecutive years; however, recurrence intervals greater than 100 years have a large amount of uncertainty associated with them, especially when the period of recorded data at a streamflowgaging station is short. As the length of record at a gaging station increases, the computed recurrence intervals become more accurate. Stationarity (the absence of trends) in peak streamflows over time is an assumption of recurrence-interval computations. The validity of this assumption is currently being investigated for peak streamflows in Maine (G. Hodgkins, U.S. Geological Survey, oral commun., 2008).

\section{Selected References}

Lombard, P.J., 2009, Flood of April 2007 in southern Maine: U.S. Geological Survey Scientific Investigations Report 2009-5102, 34 p.

National Weather Service, 2008, Daily high/low temperature and precipitation statistics: Gray, Maine, Gray Weather Forecast Office, accessed May 21, 2008, at http://www.erh.noaa.gov/er/ gyx/climate_f6.shtml\#daily_hi_lo_ precip_annual

Stewart, G.J., and Kempf, J.P., 2008, Flood of May 2006 in York County, Maine: U.S. Geological Survey Scientific Investigations Report 2008-5047, 17 p., 1 pl.

\section{By Pamela J. Lombard}

For more information, please contact:

Robert Lent, Director

U.S. Geological Survey

Maine Water Science Center

196 Whitten Road

Augusta, ME 04330

Telephone: (207) 622-8201

E-mail: rmlent@usgs.gov

Web site: http://me.water.usgs.gov 